\title{
Cultivable bacteria isolated from apple trees cultivated under different crop systems: Diversity and antagonistic activity against Colletotrichum gloeosporioides
}

João Frederico M. dos Passos ${ }^{1,2, \#}$, Pedro B. da Costa ${ }^{1, \#}$, Murilo D. Costa ${ }^{2}$, Gilmar R. Zaffari ${ }^{2}$, Gilberto Nava ${ }^{2}$, José Itamar Boneti ${ }^{2}$, Andréia Mara R. de Oliveira $^{3}$ and Luciane M.P. Passaglia ${ }^{1}$

${ }^{1}$ Departamento de Genética, Instituto de Biociências, Universidade Federal do Rio Grande do Sul, Porto Alegre, RS, Brazil.

${ }^{2}$ Empresa de Pesquisa e Extensão Agropecuária de Santa Catarina, Lages, SC, Brazil.

${ }^{3}$ Fundação Estadual de Pesquisa Agropecuária, Porto Alegre, RS, Brazil.

\begin{abstract}
This study evaluated the diversity of cultivable plant growth-promoting (PGP) bacteria associated with apple trees cultivated under different crop management systems and their antagonistic ability against Colletotrichum gloeosporioides. Samples of roots and rhizospheric soil from apple trees cultivated in organic and conventional orchards in southern Brazil were collected, together with soil samples from an area never used for agriculture (native field). Bacteria were identified at the genus level by PCR-RFLP and partial sequencing of the 16S rRNA, and were evaluated for some PGP abilities. The most abundant bacterial genera identified were Enterobacter (27.7\%), Pseudomonas (18.7\%), Burkholderia (13.7\%), and Rahnella (12.3\%). Sixty-nine isolates presented some antagonist activity against $C$. gloeosporioides. In a greenhouse experiment, five days after exposure to $C$. gloeosporioides, an average of $30 \%$ of the leaf area of plants inoculated with isolate 89 (identified as Burkholderia sp.) were infected, whereas 60 to $73 \%$ of the leaf area of untreated plants was affected by fungal attack. Our results allowed us to infer how anthropogenic activity is affecting the bacterial communities in soil associated with apple tree crop systems, and to obtain an isolate that was able to delay the emergence of an important disease for this culture.
\end{abstract}

Keywords: plant growth-promoting bacteria; apple tree; antagonistic activity; Colletotrichum gloeosporioides.

Received: February 19, 2014; Accepted: May 6, 2014.

\section{Introduction}

Apples are one of the most important cropped and consumed fruits in the world. According to Brown (2012), apples are the most produced temperate tree crop, and they are widely grown throughout almost the entire temperate climate region in the Northern and Southern hemispheres. Recently, apple cropping has been expanding into subtropical and tropical zones (Karakurt and Aslantas, 2010). To achieve intensive fruit production, which requires very high productivity and fruit quality, large agricultural inputs are required. However, the excessive use of fertilizers, in addition to increasing production costs, leads to an increase in environmental pollution. The use of more sustainable technologies, such as biofertilization, is inevitable for the

Send correspondence to Luciane M.P. Passaglia. Departamento de Genética, Instituto de Biociências, Universidade Federal do Rio Grande do Sul, Av. Bento Gonçalves 9500, Caixa Postal 15.053, Prédio 43312, 91501-970 Porto Alegre, RS, Brazil. E-mail: luciane.passaglia@ufrgs.br.

"These authors contributed equally to this work. mitigation of environmental damage (Rodriguez and Fraga, 1999; Vessey, 2003; Karakurt and Aslantas, 2010).

Interactions between the soil bacteria, the so called rhizobacteria, present in rhizospheric soils and the roots of plants have been studied intensively (Van Loon, 1997; Van Loon et al., 1998; Pieterse et al., 1996, 1998, 2001; Gozzo, 2003; Kürkcüoglu et al., 2007, Beneduzi et al., 2008; Ambrosini et al., 2012; Souza et al., 2013). Rhizobacteria are soil bacteria that colonize plant roots; they are able to multiply and occupy all the ecological niches found on the roots at all stages of plant growth (Antoun and Prévost, 2006). Such bacteria may negatively interact with plants, directly by competing for nutrients. Alternatively, the relationship between rhizobacteria and the host plant can be positive. For example, the bacteria may compete with pathogens for survival in the rhizosphere or they may promote mutualistic relationships with plants they were associated, allowing nutrient exchange and stimulating antibiotic production against phytopathogenic agents (Siddiki, 2006; Conrath et al., 2002). Root-colonizing plant-beneficial bacteria are 
commonly referred to as plant growth-promoting rhizobacteria (PGPR, Glick, 2005).

Bitter rot and leaf spot are common apple diseases that occur in countries where apple production has increased in recent years, especially in regions where the incidence of rainfall is high. They are major diseases of apple trees and are associated with yield losses up to 50\% (González et al., 2006). Under favorable conditions, for example, leaf spot disease can cause $75 \%$ defoliation and also weaken the trees (Bogo et al., 2012). Three fungi, Colletotrichum gloeosporioides, C. acutatum, and Glomerella cingulata, have been identified as the causal agents of these diseases (González et al., 2006). However, according to Bernstein et al. (1995), C. gloeosporioides and $G$. cingulata are the asexual and sexual stages of the same fungus, respectively, and the asexual isolates of this fungus (C. gloeosporioides) are the causal agent of leaf spot disease on apple trees.

Because little is known about the interactions between beneficial microorganisms and their host plants that may induce systemic resistance against phytopathogenic fungi (Kürkcüoglu et al., 2007) and how soil management affects the occurrence and distribution of the plant growthpromoting (PGP) bacteria that infect apple trees, the objectives of this study were: (1) to assess the diversity of cultivable PGPR isolated from rhizospheric soil and the roots of apple trees cultivated under different crop management systems, (2) to compare these bacterial communities with a bacterial community isolated from an area never used for agriculture, (3) to evaluate several PGP activities of the bacterial isolates, (4) to evaluate the effect of soil management on the occurrence and activity of each PGP trait, (5) to select microbial strains with the potential to stimulate plant growth and confer some resistance against $C$. gloeosporioides, and (6) to test their PGP characteristics and their ability to induce resistance against $C$. gloeosporioides in a greenhouse assay using apple trees. The results of these studies allowed us to infer how anthropogenic activity affects the soil bacterial communities associated with apple tree crop systems and to obtain an isolate that is able to delay the emergence of an important disease for this cultivar.

\section{Material and Methods}

\section{Sampling and sample preparation}

The following study sites were selected on the basis of their differences in soil management: Organic Orchard (OO), Conventional Orchard (CO), and Native Field (NF). The sites were situated in the locality of São Joaquim (28¹7'36' S, 4956' '”' W), Santa Catarina State, Brazil, at an altitude of $1,360 \mathrm{~m}$ above sea level. The climate of the region is humid mesothermic $(\mathrm{Cfb})$ according to the Köppen classification. Higher precipitation occurs from
October to March and during this period, the average monthly rainfall is around $166 \mathrm{~mm}$.

In the $\mathrm{OO}$ installation, soil acidity was adjusted to raise the $\mathrm{pH}$ to 6.0 using $50 \%$ of calcitic and $50 \%$ of dolomitic limestones. Rock phosphate and wood ashes (that contain $1.9 \mathrm{~g} \mathrm{~kg}^{-1}$ of $\mathrm{N}, 0.51 \mathrm{~g} \mathrm{~kg}^{-1}$ of $\mathrm{P}, 1.7 \mathrm{~g} \mathrm{~kg}^{-1}$ of $\mathrm{K}$, $0.6 \mathrm{~g} \mathrm{~kg}^{-1}$ of $\mathrm{Ca}$, and $0.6 \mathrm{~g} \mathrm{~kg}^{-1}$ of $\mathrm{Mg}$ ) were applied before liming for correcting the levels of $\mathrm{P}$ and $\mathrm{K}$, respectively. Before the plants start to produce (in growth fertilization), poultry litter (containing $21 \mathrm{~g} \mathrm{~kg}^{-1}$ of $\mathrm{N}, 12 \mathrm{~g} \mathrm{~kg}^{-1}$ of $\mathrm{P}$, $21 \mathrm{~g} \mathrm{~kg}^{-1}$ of $\mathrm{K}, 38 \mathrm{~g} \mathrm{~kg}^{-1}$, and $9 \mathrm{~g} \mathrm{~kg}^{-1}$ of $\mathrm{Mg}$ ) was applied on the soil surface. Fifteen tons $\mathrm{ha}^{-1}$ of wood ashes plus 3.5 tons ha $^{-1}$ of poultry litter were applied in the OO installation. When production started, only poultry litter (2 tons $\mathrm{ha}^{-1}$ year $^{-1}$ ) was used as maintenance fertilization.

In the $\mathrm{CO}$ installation, soil acidity was adjusted to raise the $\mathrm{pH}$ to 6.5 using $50 \%$ of calcitic and $50 \%$ of dolomitic limestones. Levels of P, K, B, and Zn were corrected before seedlings planting. Phosphorus was added as triple superphosphate $\left(700 \mathrm{~kg} \mathrm{ha}^{-1}\right.$ of $\left.\mathrm{P}_{2} \mathrm{O}_{5}\right)$ and lime to correct soil $\mathrm{P}$ levels; potassium was added as potassium chloride $\left(300 \mathrm{~kg} \mathrm{ha}^{-1}\right.$ of $\left.\mathrm{K}_{2} \mathrm{O}\right)$; boron was added as borax ( $40 \mathrm{~kg}$ $\left.\mathrm{ha}^{-1}\right)$; and zinc was added as zinc sulphate $\left(15 \mathrm{~kg} \mathrm{ha}^{-1}\right)$. Until the plants start to produce (growth fertilization), only nitrogen (as urea) was applied as nitrogen supply. When the plants started to produce (maintenance fertilization), nitrogen (as urea) was applied in amounts ranging from 40 to $80 \mathrm{~kg} \mathrm{ha}^{-1}$ year $^{-1}$, according to orchard age; $1.5 \mathrm{~kg}$ of potassium per ton of apple produced (as potassium chloride) was also added in this period. In addition, annually, eight foliar calcium sprays were applied every two weeks as calcium chloride $(0.4 \%)$ and one boron spray as boric acid $(0.2 \%)$, during full bloom time.

From the $\mathrm{OO}$ and $\mathrm{CO}$ sites, 12 apple trees (Malus domestica Borkhausen, Gala variety grafted over rootstock of Marubakaido variety) at least $2 \mathrm{~m}$ apart from each other were randomly selected and rhizospheric soil and root samples of each tree were collected. Sub-samples (500 g each) of rhizospheric soils from each tree were mixed to obtain a composite sample and were analyzed for clay, $\mathrm{P}, \mathrm{K}$, organic matter (OM), exchangeable $\mathrm{Al}, \mathrm{Ca}$, and $\mathrm{Mg}$ contents, and $\mathrm{pH}$ values using standard methods (Sparks et al., 1996; Table 1). At the NF sites, $500 \mathrm{~g}$ of 12 random soil samples down to a depth of $15 \mathrm{~cm}$ were collected, mixed and analyzed. The samples were collected on April 5, 2011, when each tree was 11 years old. In both orchards and in the native field, the cover crop was composed mainly by native grasses.

\section{Bacterial isolation}

To isolate root-associated bacteria, apple root samples were first sterilized by surface disinfection, by washing the roots in running tap water, followed by a $70 \%$ ethanol wash for $1 \mathrm{~min}$, a sodium hypochlorite solution (4\%) wash for $2 \mathrm{~min}$, and five serial rinses in sterilized dis- 
Table 1 - Abiotic soil characteristics of the sampling sites.

\begin{tabular}{lcccccccc}
\hline Sampling sites & $\begin{array}{c}\text { Clay } \\
(\%)\end{array}$ & $\begin{array}{c}\mathrm{pH} \\
\left(\mathrm{H}_{2} \mathrm{O}\right)\end{array}$ & $\begin{array}{c}\mathrm{P} \\
\left(\mathrm{mg} \mathrm{d}^{-3}\right)\end{array}$ & $\begin{array}{c}\mathrm{K} \\
\left(\mathrm{mg} \mathrm{d}^{-3}\right)\end{array}$ & $\begin{array}{c}\mathrm{OMC} \\
(\%)\end{array}$ & $\begin{array}{c}\mathrm{Al}_{\text {exc }} \\
\left(\mathrm{cmol}_{\mathrm{c}} \mathrm{dm}^{-3}\right)\end{array}$ & $\begin{array}{c}\mathrm{Ca}_{\mathrm{exc}} \\
\left(\mathrm{cmol}_{\mathrm{c}} \mathrm{dm}^{-3}\right)\end{array}$ & $\begin{array}{c}\mathrm{Mg}_{\mathrm{exc}} \\
\left(\mathrm{cmol}_{\mathrm{c}} \mathrm{dm}^{-3}\right)\end{array}$ \\
\hline Organic Orchard & 13 & 6.5 & $>100$ & $>400$ & 8.8 & 0.0 & 19.1 & 8.2 \\
Conventional Orchard & $>60$ & 5.3 & 8.9 & 331 & 3.8 & 0.2 & 9.7 & 4.4 \\
Native Field & 17 & 4.9 & 4.2 & 196 & 7.4 & 5.6 & 1.3 & 0.6 \\
\hline
\end{tabular}

OMC - Organic Matter Content.

exc - exchangeable.

tilled water. After disinfection, $10 \mathrm{~g}$ of roots from each sampling site was sliced with a sterile scalpel and placed into $250 \mathrm{~mL}$ Erlenmeyer flasks containing $90 \mathrm{~mL}$ of sterile saline solution $(0.85 \% \mathrm{NaCl})$.

Soil (for NF site) or rhizospheric soil (for OO and CO sites) bacteria were isolated from $10 \mathrm{~g}$ of soil from each sample and placed in $250 \mathrm{~mL}$ Erlenmeyer flasks containing $90 \mathrm{~mL}$ of sterile saline solution. The soil and the sliced root samples were incubated at $4{ }^{\circ} \mathrm{C}$ with agitation $(125 \mathrm{rpm})$ for 4-6 h. Triplicate aliquots of $0.1 \mathrm{~mL}$ of three-fold serial dilutions were inoculated into vials containing $4 \mathrm{~mL}$ of semisolid $\mathrm{N}$-free medium (NFb, LGI or LGI-P) according to the procedures recommended by Döbereiner (1998). After seven days of incubation at $28^{\circ} \mathrm{C}$, vials showing a veil-like pellicle near the surface of the medium were used to inoculate fresh vials containing the same semi-solid $\mathrm{N}$-free medium previously utilized. The cultures from the veil-like pellicles were further purified by streaking onto specific agar plates containing $20 \mathrm{mg} \mathrm{L}^{-1}$ of yeast extract and incubating them at $28^{\circ} \mathrm{C}$ for 3 days. Immediately after incubation, one colony from each plate was randomly selected and grown in liquid Luria-Bertani (LB) medium (Sambrook and Russel, 2001) at $28^{\circ} \mathrm{C}$ with agitation (125 rpm). From the $\mathrm{OO}$ and $\mathrm{CO}$ sampled sites, 60 colonies of rootassociated bacteria and 60 colonies of rhizospheric soil bacteria were isolated. From the NF sampled site 60 colonies of soil bacteria were isolated. All bacterial isolates were randomly selected from the plates. These bacterial isolates (300 in total) were individually analyzed by Gram-staining and immediately stored in sterile glycerol solution $(40 \%)$ at $-20{ }^{\circ} \mathrm{C}$.

\section{Extraction of bacterial DNA, PCR amplification, RFLP analysis and partial sequencing of the bacterial 16S rRNA gene}

To extract DNA, $2 \mathrm{~mL}$ of each bacterial culture was grown in LB medium, after which the cultures were centrifuged for $5 \mathrm{~min}$ at $12,000 \mathrm{x} \mathrm{g}$. The bacterial pellet was rinsed with $700 \mu \mathrm{L}$ of TES buffer $(10 \mathrm{mM}$ Tris $\mathrm{pH} 8.0$, $25 \mathrm{mM}$ EDTA, $150 \mathrm{mM} \mathrm{NaCl}$ ), re-centrifuged and suspended in $500 \mu \mathrm{L}$ of TE buffer $(10 \mathrm{mM}$ Tris $\mathrm{pH} 8.0,25 \mathrm{mM}$ EDTA). Cells were lysed at $37^{\circ} \mathrm{C}$ with $20 \mathrm{mg} \mathrm{mL}^{-1}$ lysozyme, $4 \%$ sodium dodecyl sulfate and $20 \mathrm{mg} \mathrm{mL}^{-1}$ proteinase $\mathrm{K}$. The samples were homogenized for $30 \mathrm{~s}$ and incubated at $56^{\circ} \mathrm{C}$ for $15 \mathrm{~min}$. To precipitate cellular waste,
$600 \mu \mathrm{L}$ of ammonium acetate ( $8 \mathrm{M} \mathrm{pH} \mathrm{8.0)}$ was added, and the samples were kept on ice for $30 \mathrm{~min}$ and subsequently centrifuged for $20 \mathrm{~min}$ at $12,000 \mathrm{x}$. Phenol-chloroform extraction and ethanol precipitation were performed as described by Sambrook and Russel (2001). The quality and integrity of the DNA were determined by electrophoresis in $0.8 \%$ agarose gels containing ethidium bromide and visualized by UV light.

Partial sequences of the 16S rRNA gene (roughly $450 \mathrm{bp}$ ) from each isolate were amplified using the primers U968 (AACGCGAAGAACCTTAC) and L1401 (CGGTGTGTACAAGACCC) (Felske et al., 1997), which cover the region between nucleotides 968 and 1401 of the Escherichia coli $16 \mathrm{~S}$ rRNA gene. Extracted DNA (50 ng) was used as a template in $25 \mu \mathrm{L}$ reactions containing $20 \mu \mathrm{M}$ of each deoxynucleoside triphosphate, $0.3 \mu \mathrm{M}$ of each primer, $2 \mathrm{mM} \mathrm{MgCl} 2$ and $2 \mathrm{U}$ of Taq polymerase (Invitrogen) in 1X Taq buffer. The reactions were performed using the PCR Express Temperature Cycling System (Thermo Hybaid) under the following conditions: an initial denaturation step at $94{ }^{\circ} \mathrm{C}$ for $5 \mathrm{~min}$ followed by 30 cycles at $94{ }^{\circ} \mathrm{C}$ for $45 \mathrm{~s}, 52^{\circ} \mathrm{C}$ for $45 \mathrm{~s}, 72{ }^{\circ} \mathrm{C}$ for $45 \mathrm{~s}$ and one cycle at $72{ }^{\circ} \mathrm{C}$ for $10 \mathrm{~min}$ for final elongation. PCR products were analyzed by electrophoresis in $1 \%$ agarose gels containing ethidium bromide and visualized under UV light.

Aliquots $(5 \mu \mathrm{L})$ of each PCR product were directly used for restriction enzyme cleavage (HaeIII and MspI) and incubated at $37^{\circ} \mathrm{C}$ for $16 \mathrm{~h}$ to ensure the complete digestion of the PCR product. RFLP analysis was performed by electrophoresis in a $10 \%$ polyacrylamide gel stained with silver nitrate (Sambrook and Russel, 2001). The gels were run for $3 \mathrm{~h}$ at $200 \mathrm{~V}$ in $1 \mathrm{X}$ Tris-borate-EDTA buffer and stained for $30 \mathrm{~min}$ in silver nitrate. This procedure was repeated at least twice for each sample to verify the consistency of the patterns. The complete restriction profiles obtained after restriction enzyme cleavage were used to distinguish each isolate. The RFLP banding profile was transformed into a two-dimensional binary matrix, where 1 was assigned for the presence and 0 for the absence of a band. The data were subjected to diversity analysis using the PAST software (Hammer et al., 2001) and by the UPGMA algorithm and Jaccard coefficient. A dendrogram showing the genetic relationships among the isolates was constructed for each sampling site studied. One representative bacteria belong- 
ing to each cluster obtained with the $16 \mathrm{~S}$ rDNA-PCRRFLP was chosen for partial sequencing of the 16S rRNA gene. Sequencing was performed on an ABI PRISM 3100 Genetic Analyzer automatic sequencer (Applied Biosystems) in the ACTGene Laboratory (Centro de Biotecnologia, UFRGS, RS, Brazil) using forward and reverse primers, as described by the manufacturer. Sequence analyses were performed with BioEdit version 7.0.9.0 software (Hall, 1999) in order to verify their quality and to check for possible chimeric origins. DNA sequences (approximately $450 \mathrm{bp}$ ) were compared with sequences from EzTaxon Server version 2.1 (Chun et al., 2007) and GenBank database using BLASTN software (Altschul et al., 1997). The nucleotide sequences of the 105 partial 16S rRNA gene segments determined in this study have been deposited in GenBank (accession numbers KF447963 to KF448068).

\section{Diversity index calculation and analysis}

The diversity index ( $H^{\prime}$; Shannon and Weaver, 1949) was estimated based on dendrograms for each sampled site by counting the number of clusters at the $70 \%$ similarity level and the number of taxa within each cluster (Borges et al., 2003; Kaschuk et al., 2006). Principal component analysis (PCA) was used to verify correlations between soil properties and the bacterial diversity index (Rico et al., 2004). The variables were normalized by division by their standard deviation, and the eigenvalues and eigenvectors of the correlation matrix were calculated, as well as the percentages of variance for each component. $H^{\prime}$ and PCA were computed using PAST software (Hammer et al., 2001).

\section{Evaluation of the characteristics that promote plant growth}

The PGP capacity of the bacterial isolates was evaluated by in vitro tests. Bacterial suspensions $\left(10 \mu \mathrm{L}\right.$ of $10^{8}$ $\mathrm{CFU} \mathrm{mL} \mathrm{mL}^{-1}$ ) of each isolate grown in $\mathrm{LB}$ medium at $28^{\circ} \mathrm{C}$ with agitation $(125 \mathrm{rpm})$ for $48 \mathrm{~h}$ were used as inocula for the PGP experiments The production of indolic compounds (ICs) and siderophores and the ability to solubilize tricalcium phosphate were evaluated for all (300) bacterial isolates and were determined as described by Ambrosini et al. (2012). For each assay the distance (in $\mathrm{mm}$ ) from the colony until the end of the halo was recorded with the aid of a digital fixed ruler (each plate was photographed with a digital camera). This measurement allowed us to infer how strong each isolate displayed each of the PGP ability evaluated.

The nitrogen-fixing ability of the five bacterial isolates selected for in vivo experiments was tested using the acetylene reduction assay (ARA) as described by Boddey (1987) and Ambrosini et al. (2012).

\section{Antagonist effect against $C$. gloeosporioides}

All bacterial isolates (300) were evaluated for their antagonistic activity against $C$. gloeosporioides. The fungal strain utilized was SJ197 that was isolated from apple trees (Gala variety) and was obtained from EPAGRI (São Joaquim Experimental Station, SC, Brazil). The assay was conducted in Petri dishes containing potato dextrose agar (PDA; Fiddaman and Rossal, 1993) medium. Each plate received in its center a small disc of culture medium containing the fungal mycelium previously grown in PDA plates in an environmental chamber at $28^{\circ} \mathrm{C}$ for 7 days. Four isolates were also inoculated into four sectors of the plate with the aid of a platinum loop. Each isolate was tested in triplicate. The antagonistic activities of the bacterial isolates were evaluated after 7 days of incubation at $28{ }^{\circ} \mathrm{C}$. Bacterial strains were classified based on their abilities to suppress fungal growth: Level 0: the mycelium grew over the bacterial colony; Level 1: the mycelium grew up to the bacterial colony; Level 2: the distance between the mycelium and the bacterial colony was from 0 to $10 \mathrm{~mm}$; and Level 3: the distance between the mycelium and the bacterial colony was larger than $10 \mathrm{~mm}$.

Greenhouse experiment on plant growth-promotion and antagonistic activity against $C$. gloeosporioides by native PGPR isolates

A greenhouse experiment was carried out using grafted apple seedlings. The grafting was performed as conducted by apple growers in the region of São Joaquim and consisted of seedlings of the apple Gala variety grafted over rootstock seedlings of a one-year old apple Marubakaido variety. After six months of growth in a greenhouse, the shoot lengths of the seedlings were approximately $50 \mathrm{~cm}$. Grafted seedlings were then transferred to $1.7 \mathrm{~L}$ pots filled with non-sterile soil as substrate. The soil was composed of a mix of an Inceptisol soil, a Nitosol soil and 1/15 composted poultry litter. Grafted seedlings were fertilized with half of the recommended dose of NPK for apple cultivation one month before the beginning of the experiment. All plants were watered to capacity without soaking the substrate every 2 days, keeping the soil moist. Five bacterial isolates were chosen for investigating PGP abilities: 75 (Burkholderia sp.), 89 (Burkholderia sp.), 108 (Pseudomonas sp.), 187 (Burkholderia sp.), and 208 (Burkholderia sp.). The bacterial isolates were grown in LB medium with agitation (125 rpm) for $48 \mathrm{~h}$ at $28^{\circ} \mathrm{C}$. Pure bacterial cultures were centrifuged and diluted to a final concentration of $10^{8} \mathrm{CFU}$ $\mathrm{mL}^{-1}$ in sterile saline solution. Apple seedlings were directly inoculated on the roots with $5 \mathrm{~mL}$ aliquots of the bacterial suspensions. An extra bacterial inoculation was performed for those plants that received the fungal inoculum in the same day of fungal spraying. Fungal inocula (C. gloeosporioides strain SJ197) were previously prepared in PD liquid medium in an environmental chamber at $28^{\circ} \mathrm{C}$ for 7 days and were diluted to a concentration of $10^{6}$ conidia $\mathrm{mL}^{-1}$. The leaves of the plants were sprayed with a fungal culture and left in a moist chamber for $48 \mathrm{~h}$ at 
$28^{\circ} \mathrm{C}$. After this period, the infected plants were placed in the greenhouse with the plants that had not received the fungus, and all pots were distributed in a completely randomized design distant at least $30 \mathrm{~cm}$ from each other to avoid fungal or bacterial cross contamination. The experiment had one plant per pot and consisted of the following treatments: (1) plant without inoculation of bacterial isolate and without inoculation of the fungus (control); (2) plant inoculated with a bacterial isolate and without the inoculation of fungus; (3) plant inoculated with a bacterial isolate plus inoculation with fungus; and (4) plant without the inoculation of a bacterial isolate and inoculated with fungus. The experiment consisted of seven replicates per treatment. The plants were irrigated every two days with running water without micro- or macronutrients. The experiment was maintained for 30 days, after which several parameters were evaluated. The plants were harvested and length data were recorded. Shoots and roots were dried at $65^{\circ} \mathrm{C}$ to constant weight to evaluate dry matter. All shoot dry matter from each treatment was combined for elemental analysis. Shoot nutrient content was determined by the Kjeldahl method (detection limit $0.01 \%$ ) for $\mathrm{N}$ and nitric-perchloric wet digestion/ICP-OES (Inductively Coupled Plasma-Optical Emission Spectrometry; detection limit $0.01 \%$ ) for $\mathrm{P}$ and $\mathrm{K}$. The nutrient content of the plants was estimated for each treatment by the uptake per gram of plant tissue multiplied by total yield per treatment [(yield) $\mathrm{X}$ (percent nutrient per gram of plant tissue)] (Adesemoye and Kloepper, 2009).

Incidence and severity of fungal symptoms were evaluated in eight leaves per tree, totaling 56 leaves for each treatment, in the second and sixth days after fungal spraying. The incidence and severity were quantified by a specific diagrammatic scale (Kowata et al., 2010). The data were used to calculate the area under the disease progress curve (AUDPC) by trapezoidal integration value of incidence and severity (Campbell and Madden, 1990).

\section{Statistical analysis}

The occurrence of PGP traits and genera in the different soil management conditions was tested by Chi-Square exact $\mathrm{p}$ value and adjusted residual analysis. The phenotype of PGP traits (halo sizes and ICs production) between isolates from different soil types and genera was compared with one-way ANOVA followed by Tukey's HSD test, after logarithmic transformation. Comparisons between rhizospheric and root-associated bacteria of the main genera in different soil management conditions were performed with factorial two-way ANOVA, except for phosphate solubilization, where we used a Student's $t$-test since only strains belonging to Rhanella genus presented phosphate solubilization activity on both niches. Student's $t$-test was also used to individually compare the phenotype of PGP traits from rhizospheric and root-associated bacteria of the different orchards. A correlation between sidero- phores production and antagonism was verified with Pearson's test.

Data from the greenhouse growth experiment were analyzed using one-way ANOVA, followed by Tukey's HSD test. The greenhouse biocontrol experiment was evaluated with a unilateral Student's $t$-test with log transformation, comparing to control.

All statistical assumptions for ANOVA, Student's and Pearson's tests were verified, using log transformation or Student's test for unequal variances when needed. Due to violation of assumptions in ICs comparison among the most important genera, we performed a Kruskal-Wallis test followed by Mann-Whitney pair-wise comparisons with Bonferroni correction. Differences were considered significant if $\mathrm{p}<0.05$. Statistical analyses were done using IBM SPSS Statistics version 19 (SPSS, 2010) and Past Version 2.09 .

\section{Results}

Isolation, identification, and diversity of putative diazotrophic roots and rhizospheric bacteria

A total of 300 bacterial strains were selectively isolated from the rhizospheric soil or roots of apple trees or from soil of a native field based on their growth in one of three semi-selective semi-solid media without nitrogen; i.e., $\mathrm{NFb}$, LGI or LGI-P. These $\mathrm{N}$-free media were used as part of a strategy to select putative nitrogen-fixing and plant growth-promoting bacteria. Root, rhizospheric and soil bacteria belonging to different species were discriminated by PCR-RFLP of the 16S rRNA gene using two restriction enzymes, HaeIII and MspI. The RFLP patterns were used to construct a dendrogram for each site (Figure S1), and a representative strain from each cluster was chosen for the $16 \mathrm{~S}$ rRNA partial gene sequence analysis. The community composition according to the occurrence of each bacterial genus in each condition is shown in Figure 1.

Twenty-seven different bacterial genera were identified. While bacteria from the Enterobacter, Pseudomonas and Burkholderia genera were present in all sampling sites, the proportions were strikingly different (Figure 1). Strains belonging to Enterobacter and Burkholderia genera were overrepresented in NF, while strains belonging to the Pseudomonas genus were more abundant in the $\mathrm{CO}$ condition. The OO condition was marked with a very low occurrence of Burkholderia strains. Bacteria belonging to Cedecia, Leclercia and Stenotrophomonas genera occurred at both orchards, with the first two genera associated with $\mathrm{CO}$ and the latter associated with OO. The other two abundant bacterial genera identified were Ewingella and Rahnella, which were clearly associated with $\mathrm{CO}$ and $\mathrm{OO}$, respectively. These eight genera, which accounted for approximately $30 \%$ of the total taxonomical diversity, contained $85 \%$ of the isolates, suggesting that they dominate the soil population in the analyzed conditions. 


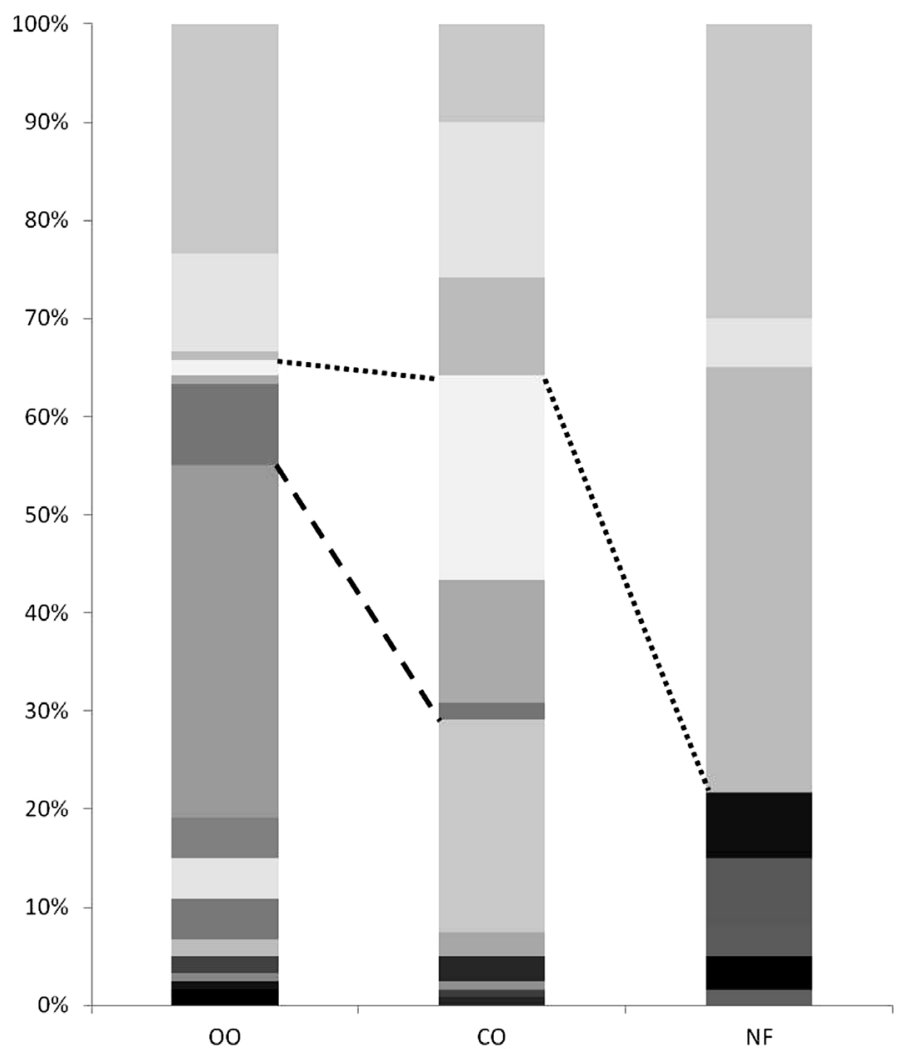

\begin{tabular}{|c|c|c|c|}
\hline Genera & $\mathrm{OO}$ & $\mathrm{CO}$ & $\mathrm{N}$ \\
\hline Enterobacter sp. & 28 & $\underline{12}$ & 1 \\
\hline Pseudomonas sp. & 12 & 19 & 3 \\
\hline Burkholderia sp. & $\underline{1}$ & 12 & 2 \\
\hline Cedecia sp. & $\underline{2}$ & 25 & $\underline{0}$ \\
\hline Leclercia sp. & $\underline{1}$ & 15 & $\underline{v}$ \\
\hline EStenotrophomonas sp. & 10 & 2 & \\
\hline Rahnella sp. & 43 & $\underline{0}$ & $\underline{0}$ \\
\hline Ewingella sp. & $\underline{0}$ & 26 & \\
\hline Rhizobium sp. & 5 & 0 & 0 \\
\hline Raoultella sp. & 5 & 0 & c \\
\hline — Pantoea sp. & 5 & 0 & c \\
\hline - Serratia sp. & 0 & 0 & s \\
\hline - Leifsonia sp. & 0 & 0 & 5 \\
\hline Kluyverasp. & 0 & 3 & c \\
\hline Erwinia sp. & 0 & 3 & 0 \\
\hline Obesumbacterium sp. & 2 & 0 & c \\
\hline Microbacterium sp. & 0 & 0 & 2 \\
\hline - Luteibacter sp. & 0 & 0 & 2 \\
\hline Achromobacter sp. & 2 & 0 & $c$ \\
\hline Paenibacillus sp. & 1 & 0 & c \\
\hline - Marinobacterium sp. & 1 & 0 & c \\
\hline Herbaspirillum sp. & 0 & 1 & c \\
\hline Eafnia sp. & 0 & 1 & c \\
\hline - Citrobacter sp. & 1 & 0 & c \\
\hline - Bordetella sp. & 0 & 1 & c \\
\hline arthrobacter sp. & 0 & 0 & t \\
\hline - Acinetobacter sp. & 1 & 0 & c \\
\hline Number of isolate & 120 & 120 & 6 \\
\hline
\end{tabular}

Figure 1 - Bacterial community composition from soil under different management conditions. Different gray shades represent the dominance of each genus in each soil condition (represented by bars). Genera above the dotted line were ubiquitous, and genera between the dotted and dashed lines occurred under both orchards. Bold $=$ excessive number of bacteria occurring in that condition; Underline $=$ less bacteria than expected occurring in that condition. $\mathrm{NF}=$ Native field, $\mathrm{CO}=$ Conventional Orchard, $\mathrm{OO}=$ Organic Orchard.

Principal coordinate analysis (PCA) was used to investigate the relationship between bacterial diversity $\left(H^{\prime}\right)$ and abiotic soil parameters (Figure 2). Principal component (PC) 1 accounted for $62.19 \%$ of the total variation and separated exchangeable $\mathrm{Al}$ and clay, on the left side, from all other variables. PC2 represented $37.81 \%$ of the total varia-

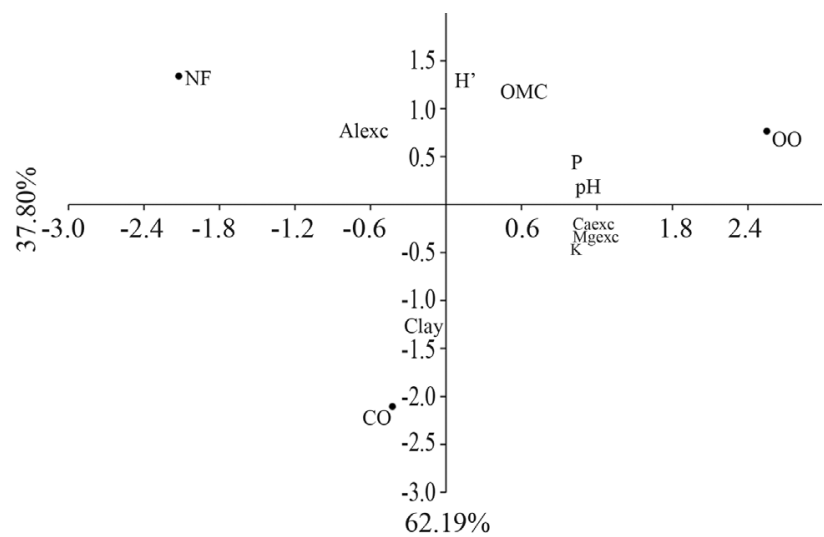

Figure 2 - Principal component analysis (PCA) of the diversity indexes $\left(H^{\prime}\right)$ and soil properties [clay, organic matter content (OMC), $\mathrm{pH}, \mathrm{P}, \mathrm{K}$, $\mathrm{Mg}_{\text {exc }}, \mathrm{Ca}_{\mathrm{exc}}$, and $\left.\mathrm{Al}_{\text {exc }}\right]$ of the three sampling sites. Principal component 1 and 2 accounted for $62.19 \%$ and $37.81 \%$ of the total variation, respectively. $\mathrm{NF}=$ Native Field; $\mathrm{CO}=$ Conventional Orchard; $\mathrm{OO}=$ Organic Orchard. tion and separated $\mathrm{P}, \mathrm{pH}, H^{\prime}, \mathrm{OMC}$ and exchangeable $\mathrm{Al}$ from the other variables on the upper side of the plot. This analysis shows that the soil clay content was more closely related to $\mathrm{CO}$, while exchangeable $\mathrm{Al}$ was more closely related to NF; the other variables (including OMC) were more related to $\mathrm{OO}$. The bacterial diversity index of $\mathrm{CO}$ was higher $\left(H^{\prime}=2.04\right)$ than for $\mathrm{OO}\left(H^{\prime}=1.98\right)$ and $\mathrm{NF}$ $\left(H^{\prime}=1.55\right)$.

\section{PGP traits of bacterial isolates}

Table 2 shows the occurrence of PGP traits of each sampling site by niche. Figure 3 shows the effect of soil management on the occurrence and activity of each PGP traits by sampling site.

To study the effects of soil management on PGP traits, we evaluated the occurrence of the traits per condition using chi-square, and then evaluated the phenotype of positive isolates with ANOVA-Tukey. According to our results, the $\mathrm{OO}$ condition stimulated the occurrence of siderophore producers (Table 2), but their halo sizes were smaller than in the other conditions. This system was also associated with a sharp increase of good indolic compounds producers (Figure 3). The $\mathrm{CO}$ condition was associated with a decrease in the number of siderophore producers but an increase in the number of phosphate solubilizers and ICs pro- 
Table 2 - Ocurrence of siderophore and indolic compound (ICs) production, phosphate solubilization, and antagonistic activity of bacterial isolates by sampling site and niche.

\begin{tabular}{|c|c|c|c|c|c|c|}
\hline Sampling sites & Source & Number of isolates & $\begin{array}{l}\text { Siderophore } \\
\text { producers }\end{array}$ & $\begin{array}{l}\text { Phosphate } \\
\text { solubilizers }\end{array}$ & $\begin{array}{l}\text { Antagonistic } \\
\text { activity }\end{array}$ & ICs producers \\
\hline Native Field & Soil & 60 & 42 & 0 & 12 & 49 \\
\hline Conventional Orchard & Roots & 60 & 30 & 0 & 11 & 60 \\
\hline Conventional Orchard & Rhizospheric soil & 60 & 38 & 21 & 21 & 60 \\
\hline Organic Orchard & Roots & 60 & 52 & 5 & 13 & 59 \\
\hline Organic Orchard & Rhizospheric soil & 60 & 52 & 10 & 12 & 55 \\
\hline Total & & 300 & 214 & 36 & 69 & 283 \\
\hline
\end{tabular}

ducers. The $\mathrm{CO}$ condition also showed a higher number of phosphate solubilizers with bigger halo sizes; in this system the halo size displayed by the isolates for the antagonism assay was smaller than the isolates from NF. The NF condition presented a reduced number of phosphate solubilizers and ICs producers, but the isolates from this condition presented the largest halo sizes for siderophore production and antagonism assays.

We also carried out several comparisons between rhizospheric soil and root-associated isolates with the same statistical approach. We found that only the phosphate solubilization ability was different between rhizospheric soil and root-associated isolates from the $\mathrm{OO}$ and $\mathrm{CO}$ conditions, at both occurrence and expression. There were more phosphate solubilizers on $\mathrm{CO}$ soils than on $\mathrm{CO}$ root tissues, and the halo sizes displayed by phosphate solubilizers isolated from $\mathrm{OO}$ soils were larger than those from OO root tissues (Figure S2).

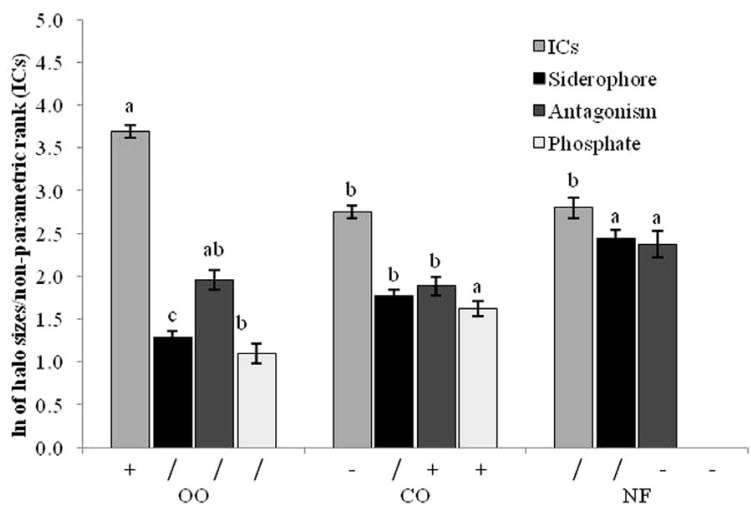

Figure 3 - Occurrence and activity of PGP traits of bacterial isolates from different management conditions. ANOVA-Tukey comparisons were made across each single PGP trait independently, so each statistical analysis compares bars with the same color. Bars show the activity of positive isolates for each PGP trait; different letters show significant differences. +, I, and - signs below the bars show the association between the soil management and the occurrence of the characteristic, as per adjusted residue analysis: $+=$ excessive number of bacteria displaying that characteristic in that condition; - = less bacteria then expected displaying that characteristic in that condition; / = number of isolates displaying that characteristic in that condition falls within expected range. $\mathrm{OO}=$ Organic Orchard, $\mathrm{CO}=\mathrm{Con}-$ ventional Orchard, $\mathrm{NF}=$ Native Field. The scale is the natural log value of original values (in $\mathrm{mm}$ ) for siderophores production, phosphate solubilization and antagonism assays. ICs production is in $\mathrm{mg} \mathrm{mL}^{-1}$.
With the most abundant genera in the community identified (Figure 1), we compared their specific PGP traits. Figure 4 shows the PGP traits of the eight most abundant genera found in both rhizospheric soil and root samples. All PGP traits were different among the main genera, and no single genera presented high scores for all PGP traits evaluated. Strains belonging to Burkholderia sp. presented the best results for siderophores production, antagonistic action against the fungus $C$. gloeosporioides and phosphate solubilization ability. Production of indolic compounds was higher in strains belonging to the Rahnella and Enterobacter genera.

We also analyzed interaction effects between the PGP traits of ubiquitous bacteria and soil management. There were no significant interaction effects, suggesting that soil management did not significantly change the PGP traits of strains belonging to Burkholderia, Enterobacter and Pseudomonas genera (data not shown). Finally, we compared root-associated and rhizospheric soil isolates of the same genera and observed that strains belonging to the Rahnella genus had a significant niche effect on phosphate solubilization ability, with the largest halo sizes found in the isolates from rhizospheric soil samples (Figure S3A). Strains belonging to the Burkholderia genus also seem to have a niche effect on siderophores production ability, with the largest halo sizes identified in the isolates from rhizospheric soil samples (Figure S3B).

Based on their taxonomic identification and their PGP traits (non-pathogenic bacterium, high antagonistic activity against pathogenic fungus, and presence of some PGP traits), five isolates were selected for inoculating apple tree seedlings in a greenhouse experiment. The isolates chosen were 75, 89, 108, 187, and 208. Their identifications and PGP abilities are shown in Table 3. The selected isolates were all able to produce siderophores, but only one of them was a tricalcium phosphate solubilizer (isolate 208). Nevertheless, the isolates were also chosen according to their high antagonistic activity against $C$. gloeosporioides and their ability to fix nitrogen.

\section{Plant assay}

The inoculation of apple seedlings with the five isolates did not result in significant effects on the length, shoot 


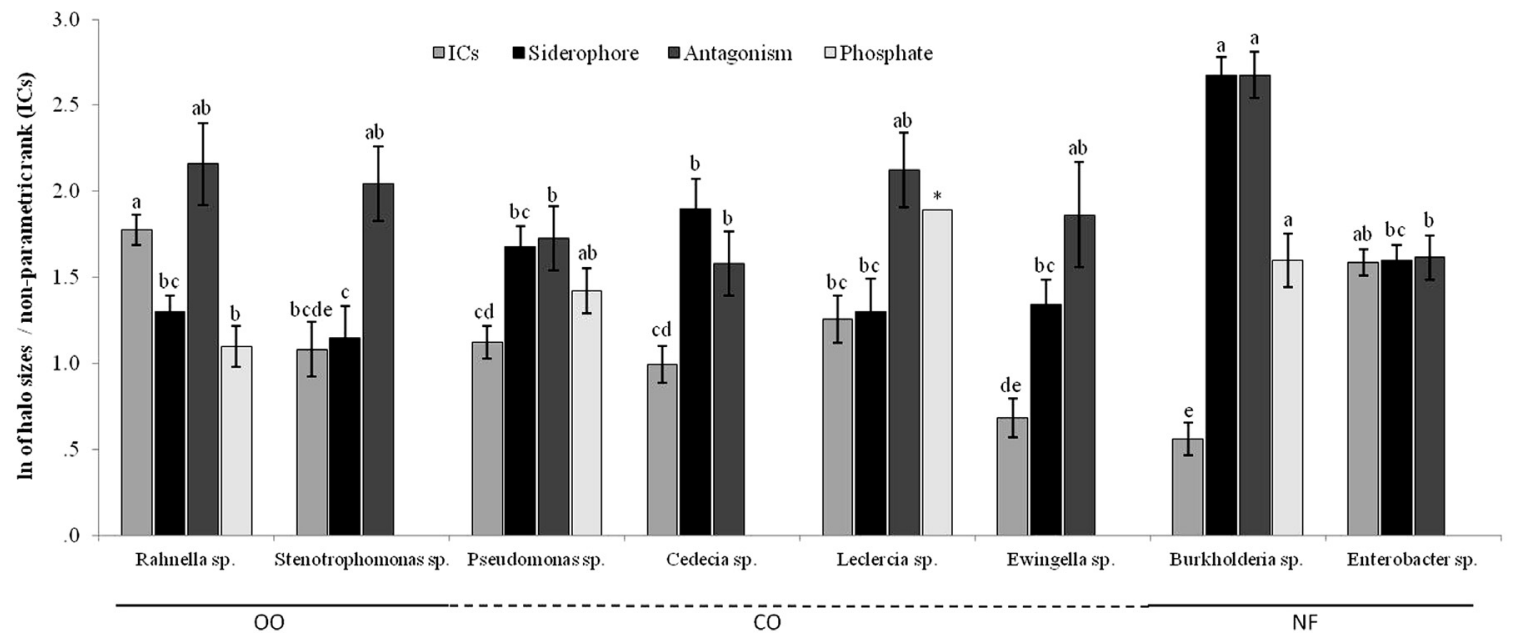

Figure 4 - PGP traits of the genera composing the core of the microbial communities (average \pm SEM). Comparisons were made across each single PGP trait independently, so each statistical analysis compares bars with the same color. Siderophores, antagonism against $C$. gloeosporioides and phosphate solubilization abilities were compared according to halo size. ICs production ability was compared by non-parametric ranking and scaled down 100 times for graphical display. The genera are arranged according with the type of soil management to which they were positively associated. *= phosphate solubilization for strains belonging to Leclercia genus were removed from the statistical analysis because only one isolate presented this trait, so the standard deviation could not be calculated for this genus. $\mathrm{OO}=$ Organic Orchard, $\mathrm{CO}=$ Conventional Orchard, $\mathrm{NF}=$ Native Field.

Table 3 - Identification and PGP abilities of the selected isolates.

\begin{tabular}{llccccc}
\hline Isolates $^{\mathrm{a}}$ & 16S rRNA sequence & $\begin{array}{c}\text { Siderophore } \\
\text { production }\end{array}$ & $\begin{array}{c}\text { Phosphate } \\
\text { solubilization }\end{array}$ & $\begin{array}{c}\text { ICs production } \\
\left(\mu \mathrm{mL}^{-1}\right)\end{array}$ & $\begin{array}{c}\text { Antagonistic activity } \\
(\mathrm{mm})\end{array}$ & $\begin{array}{c}\mathrm{ARA}\left(\mathrm{nmol} \mathrm{C} \mathrm{H}_{4} \mathrm{mg}\right. \\
\left.\text { protein }^{-1}\right)\end{array}$ \\
\hline 75 & Burkholderia sp. & + & - & 7.23 & 20 & $15.6 \pm 15.7^{\mathrm{a}}$ \\
89 & Burkholderia $\mathrm{sp}$. & + & - & 15.56 & 21 & $4.9 \pm 1.1^{\mathrm{a}}$ \\
108 & Pseudomonas sp. & + & - & 28.77 & 19 & $8.5 \pm 6.7^{\mathrm{a}}$ \\
187 & Burkholderia sp. & + & - & 6.46 & 21 & $25.2 \pm 13.8^{\mathrm{a}}$ \\
208 & Burkholderia sp. & + & + & 10.39 & 23 & $16.7 \pm 4.5^{\mathrm{a}}$ \\
\hline
\end{tabular}

ICs (Indolic compounds); ARA (Acetylene Reduction Assay).

${ }^{a}$ Bacterial strains isolated: 75 and 89 from soil/native field sample; 108 from rhizospheric soil/organic orchard sample; 187 and 208 from rhizospheric soil/conventional orchard sample.

and root dry matter, which is most likely due to the short period of evaluation (Table S1). However, the inoculation of apple seedlings with isolates 75 and 208 resulted in different effects on phosphorus (P) uptake of the plants compared to control plants (Table 4).

When apple seedlings were submitted to bacterial plus fungal inoculation, no significant effects were observed on the length, shoot and root dry matter (Table S1). Analysis of the uptake of nitrogen $(\mathrm{N}), \mathrm{P}$ and $\mathrm{K}$ by the treated apple seedlings revealed that the uptake of $\mathrm{P}$ (Table 5) in plants inoculated with isolate 208 corroborated the results obtained with this isolate when plants were submitted to bacterial inoculation without fungus.

To evaluate the potential of the five bacterial isolates to induce systemic resistance against the phytopathogenic fungus, apple seedlings were also analyzed according disease development after fungal inoculation. Five days after fungal spraying, the percentage of necrotic leaf area was evaluated for each plant inoculated with bacterial isolates
Table 4 - The effect of the inoculation of native PGPR on the uptake of N, $\mathrm{P}$ and $\mathrm{K}$ by apple seedlings in the greenhouse assay.

\begin{tabular}{lccc}
\hline Treatment & \multicolumn{3}{c}{ Nutrient uptake } \\
\cline { 2 - 4 } & $\mathrm{N}(\%)$ & $\mathrm{P}(\%)$ & $\mathrm{K}(\%)$ \\
\hline Control $^{\mathrm{a}}$ & $1.59 \pm 0.45^{\mathrm{a}}$ & $0.20 \pm 0.05^{\mathrm{b}}$ & $1.59 \pm 0.27^{\mathrm{ab}}$ \\
$75^{\mathrm{b}}$ & $1.38 \pm 0.51^{\mathrm{a}}$ & $0.29 \pm 0.03^{\mathrm{a}}$ & $1.63 \pm 0.09^{\mathrm{a}}$ \\
89 & $1.43 \pm 0.60^{\mathrm{a}}$ & $0.27 \pm 0.06^{\mathrm{ab}}$ & $1.63 \pm 0.46^{\mathrm{a}}$ \\
108 & $1.48 \pm 0.46^{\mathrm{a}}$ & $0.25 \pm 0.03^{\mathrm{ab}}$ & $1.21 \pm 0.10^{\mathrm{b}}$ \\
187 & $1.53 \pm 0.23^{\mathrm{a}}$ & $0.23 \pm 0.06^{\mathrm{ab}}$ & $1.29 \pm 0.13^{\mathrm{ab}}$ \\
208 & $1.33 \pm 0.37^{\mathrm{a}}$ & $0.30 \pm 0.05^{\mathrm{a}}$ & $1.52 \pm 0.22^{\mathrm{ab}}$ \\
\hline
\end{tabular}

${ }^{\text {a }}$ Plants without bacterium inoculation.

${ }^{\mathrm{b}}$ Plants with bacterium inoculation.

The data represent the means of seven plots per treatment in the greenhouse assay followed by the standard deviation. Values in the same column followed by the same letter did not differ significantly at $\mathrm{p}>0.05$ (Tukey's test). 
Table 5 - The effect of the inoculation of native PGPR plus the pathogenic fungus on the uptake of $\mathrm{N}, \mathrm{P}$ and $\mathrm{K}$ by apple seedlings in the greenhouse assay.

\begin{tabular}{lccc}
\hline \multirow{2}{*}{ Treatment } & \multicolumn{3}{c}{ Nutrient uptake } \\
\cline { 2 - 4 } & $\mathrm{N}(\%)$ & $\mathrm{P}(\%)$ & $\mathrm{K}(\%)$ \\
\hline Fungus $^{\mathrm{a}}$ & $1.93 \pm 0.37^{\mathrm{a}}$ & $0.20 \pm 0.04^{\mathrm{b}}$ & $1.38 \pm 0.31^{\mathrm{a}}$ \\
$75+\mathrm{F}^{\mathrm{b}}$ & $1.61 \pm 0.86^{\mathrm{a}}$ & $0.29 \pm 0.11^{\mathrm{ab}}$ & $1.54 \pm 0.57^{\mathrm{a}}$ \\
$89+\mathrm{F}$ & $1.67 \pm 0.54^{\mathrm{a}}$ & $0.23 \pm 0.04^{\mathrm{ab}}$ & $1.39 \pm 0.34^{\mathrm{a}}$ \\
$108+\mathrm{F}$ & $1.73 \pm 0.57^{\mathrm{a}}$ & $0.30 \pm 0.04^{\mathrm{ab}}$ & $1.66 \pm 0.23^{\mathrm{a}}$ \\
$187+\mathrm{F}$ & $1.79 \pm 0.24^{\mathrm{a}}$ & $0.31 \pm 0.08^{\mathrm{ab}}$ & $1.47 \pm 0.23^{\mathrm{a}}$ \\
$208+\mathrm{F}$ & $1.86 \pm 0.52^{\mathrm{a}}$ & $0.32 \pm 0.07^{\mathrm{a}}$ & $1.80 \pm 0.30^{\mathrm{a}}$ \\
\hline
\end{tabular}

${ }^{\text {a} P l a n t s ~ w i t h o u t ~ b a c t e r i u m ~ i n o c u l a t i o n ~ a n d ~ w i t h ~ f u n g u s ~}(C$. gloeosporioides) inoculation.

${ }^{b}$ Plants with bacterium plus fungus inoculation.

The data represent the means of seven plots per treatment in the greenhouse assay followed by the standard deviation. Values in the same column followed by the same letter did not differ significantly at $\mathrm{p}>0.05$ (Tukey's test).

and C. gloeosporioides conidia. The plants inoculated with isolate 89 (Burkholderia sp.) had a significant lower AUDPC ( $86 \pm 13)$ than control (154 \pm 30$)$ (Figure 5). This result indicates that isolate 89 conferred some resistance to leaf spot disease in apple seedlings, slowing its progression. This isolate could be of high agronomic potential because it would give to the producer time to remove branches with leaves affected by fungal attack, or even to scarify the entire tree, preventing the disease spreading to other plants.

\section{Discussion}

The distribution of bacteria in the rhizospheric soil and roots of plants are influenced by many factors, including the host plant, the stage of plant growth and cropping practices (such as tillage and crop rotation). Plant breeding programs are oriented to select plants with resistance to disease and efficient nutrient assimilation to retain productiv-

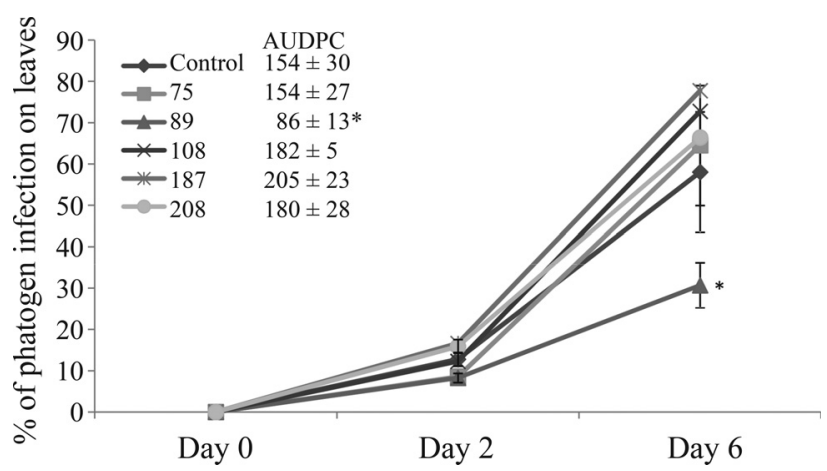

Figure 5 - Percentage of pathogen infection (average \pm SE) and area under the disease progress curve (AUDPC) in the leaves of apple tree seedlings inoculated with bacterial isolates $(75,89,108,187$ and 208) plus $C$. gloeosporioides conidia. ${ }^{*}=$ significant difference compared to control. ity, while improving quality and safety by reducing pesticide and fertilizer inputs (Bosco et al., 2006). The resistance of plants to root diseases as well as efficient nutrient assimilation is profoundly influenced by the presence and activity of beneficial microorganisms in the soil. However, plant breeding programs and a low input of organic fertilizers take longer to demonstrate effectiveness because this strategy depends on the capacity of plants to interact with their own rhizospheric microflora (Picardi et al., 2005).

In this study, cultivable bacteria associated with rhizospheric soil and roots of apple trees $(M$. domestica Borkhausen) cultivated under different soil management systems were isolated based on their growth on three selective semi-solid media without nitrogen. The 300 bacterial isolates identified were used to verify whether possible changes in the microbial communities were associated with different apple orchard management systems compared to a native field. Twenty-seven different bacterial genera were identified. To date, few studies have been conducted to study the bacterial diversity associated with the rhizosphere of apple trees. St. Laurent et al. (2008) showed that the composition of the bacterial community of the apple tree rhizosphere was not dominated by any particular group of bacteria. In our work, no dominant group of bacteria was identified, although some genera were more abundant. Strains belonging to Enterobacter, Pseudomonas, Burkholderia, Cedecia, Leclercia, Stenotrophomonas, Rhanella and Ewingella genera were the most abundant among all the bacterial genera identified in all the sampling sites, representing $84.31 \%$ of the total isolates identified. Isolates belonging to Enterobacter, Pseudomonas and Burkholderia genera were present in all soil conditions, representing $43.67 \%$ of the total bacterial isolates. Bacteria belonging to these three genera and displaying some PGP ability have been isolated from the rhizosphere of apple trees in previous studies (Karakurt and Aslantas, 2010). Our results indicated that bacteria belonging to the Enterobacteriaceae family were the most abundant in association with the roots of apple trees. Strains belonging to the Enterobacteriaceae family have also been found to be associated with a large number of plant species, such as citrus (Araújo et al., 2001), maize (Hinton and Bacon, 1995; McInroy and Kloepper, 1995), rice (Engelhard et al., 2000; Gyaneshwar et al., 2001; Rosenblueth et al., 2004; Verma et al., 2004), sweet potato (Asis and Adachi, 2003; Reiter et al., 2003), soybean (Kuklinsky-Sobral et al., 2004), and wheat (Iniguez et al., 2005).

Microorganisms can contribute to the nutrition of plants through a number of mechanisms, including direct effects on the availability of nutrients or plant growthpromoting substances, which are synthesized by the bacterium, or by facilitating the absorption of certain nutrients from the environment. Soil microorganisms may affect the growth of plants using any one or more of these mecha- 
nisms (Ahmad et al., 2006; Farina et al., 2012). In the present study, 214 isolates $(71.33 \%)$ were able to produce siderophores. Similar numbers of siderophore-producing bacteria have been documented by other studies (Adesina et al., 2007; Tian et al., 2009). Ambrosini et al. (2012) evaluated the diversity of cultivable siderophore-producing bacteria in association with the sunflower (Helianthus annus L.) rhizosphere and found that $78.26 \%$ of the 299 isolates examined produced siderophores in Fe-limited media. The results obtained in the present work could be associated to the fact that in the soil of the conventional orchard there are low amount of available nutrients and organic matter resulting in a less favorable environment to the growth of many plants and for many species of microorganisms. This situation could favor the selection of microorganisms more adapted to this limiting condition, such as, for example, those able to produce siderophores, which bind to the available form of iron $\left(\mathrm{Fe}^{3+}\right)$ in the rhizosphere, thus making it unavailable to the phytopathogens and protecting plant health. On the other hand, only $36(12 \%)$ of the isolates analyzed in this work were able to solubilize tricalcium phosphate. Similarly low numbers of phosphate-solubilizing bacteria have been documented by Beneduzi et al. (2008), who studied PGPR associated with rice, and Ambrosini et al. (2012), who studied sunflowers. Those authors found that only $7.43 \%$ and $19.73 \%$, respectively, of all PGPR characterized presented this ability.

Another important feature that can influence plant growth is the production of indolic compounds (phytohormones). These compounds stimulate root growth and increase root length, resulting in a larger root surface area that enables the plant to access more nutrients from the soil (Karakurt and Aslantas, 2010; Souza et al., 2013). Almost all of the isolates in this study (94.33\%) displayed the ability to produce indolic compounds at some level. Similar data were also reported by Farina et al. (2012) and Souza et al. (2013), who reported that $98 \%$ and $97.95 \%$ of PGPR isolated from canola and rice, respectively, displayed this ability. In the present work, the soil derived from the organic orchard contained the largest number of isolates producing high levels of indolic compounds. This result suggests that soils with a relatively high amount of organic matter $(8.8 \%)$ favored the occurrence of microorganisms that promote plant growth through the production of phytohormones. On the other hand, in the soil derived from the conventional orchard, where the organic matter content $(3.8 \%)$ and the amount of soluble phosphorus $\left(8.9 \mathrm{mg} \mathrm{d}^{-3}\right)$ were lower than in the soil derived from the organic orchard, an increased halo size for phosphate solubilization was noted. This observation suggests that in this situation of low concentration of organic matter and low amount of soluble phosphorus in soil, bacteria able to solubilize phosphates may contribute to a better adaptation of the host plant to the environment. For the soil obtained from the native field, which contained a lower amount of nutrients such as $\mathrm{Ca}, \mathrm{P}, \mathrm{K}$, and $\mathrm{Mg}$, and a higher concentration of $\mathrm{Al}$, more bacterial isolates with the greatest ability to produce siderophores and that more efficiently produce antagonistic substances against the fungus $C$. gloeosporioides were present. This result suggests that in this environmental condition, there is a strong competition for metal nutrients between the microbial species and that some of them are able to produce molecules with antagonistic action against the growth of other microorganisms. Alternatively, the siderophores in this sampling site could be acting on Al toxicity alleviation. The effect of the relief of Al toxicity and increased productivity was observed in cowpea using Streptomyces sp. (Dimkpa et al., 2009).

Although no significant effect was observed in the growth of apple seedlings with the five selected isolates, the plants inoculated with isolate 208 had higher levels of phosphorus uptake either in the absence or in the presence of fungal inoculation. Isolate 208 was identified as Burkholderia sp. and it was the only isolate that displayed the ability to solubilize tricalcium phosphate in the in vitro assay. Many studies have shown that bacterial inoculation can increase the availability of insoluble nutrients (Cole et al., 1978). Freitas et al. (1997), for example, showed that canola plants inoculated with phosphate-solubilizing bacteria had significantly enhanced growth when fertilized with rock phosphate. Similar effects were observed in maize (Laheuerte and Berthelin, 1988), sugarcane (Sundara et al., 2002) and barley (Belimov et al., 1995). Sixty-nine (23\%) of the 300 bacterial strains isolated in this work had antagonistic activity against $C$. gloeosporioides, the pathogen responsible for apple leaf spot disease. In the in vivo assay, plants inoculated with isolate 89 (also identified as another strains belonging to the Burkholderia genus.) had a delayed appearance of disease symptoms. Ramamoorthy et al. (2001) showed that some PGPR induce systemic resistance by strengthening the physical and mechanical strength of the cell wall, as well as altering the biochemical and physiological reaction of the host plant that leads to the synthesis of chemical defense against the pathogen. Moreover, it is well documented in the literature that Burkholderia species are able to synthesize a remarkable array of metabolites, including siderophores, antibiotics, and phytohormones (Vial et al., 2007), and many strains belonging to this genus exhibit activities involved in bioremediation or biological control in vitro (Caballero-Mellado et al., 2007). Strains belonging to this genus are also known for the ability to improve plant growth, for example in maize (Ciccillo et al., 2002), onion (Sessitsch et al., 2005), rice (Ait Barka et al., 2006), tomato (Caballero-Mellado et al., 2007) and sunflower (Ambrosini et al., 2012). Some of these features may explain the observed antifungal behavior of the strain of Burkholderia isolated in the present work (isolate 89) both in in vitro and in vivo tests. It will be important to identify isolate 89 at species level and determine which sub- 
stance is produced by this isolate that inhibits fungal growth to improve its biotechnological potential.

\section{Conclusions}

The results presented here suggest the presence of a diverse population of plant growth-promoting bacteria associated with apple trees. Whenever a genus was present in more than one management type, it was also significantly associated with one of the soil management types. This observation suggests that the "core" microbial community from these conditions is plastic, either able to adapt to particular differences within the analyzed soils or is easily manipulated by the host plants. We also describe which PGP trait could shift according to soil management type, niche and bacterial genera. This suggests that the phenotype of parts of the PGPR community may change according to micro and macro environmental conditions at different scales. One isolate (89, identified as Burkholderia sp.) proved to be very efficient in the induction of resistance of apple trees against the effects of the plant pathogenic fungus $C$. gloeosporioides, delaying the appearance of disease symptoms. This strain could be useful in the formulation of new inoculants, improving the cropping systems into which it can be most profitably applied.

\section{Acknowledgments}

This work was financed by a grant and fellowship from Empresa Brasileira de Pesquisa Agropecuária (Embrapa/Brazil) and Instituto Nacional de Ciência e Tecnologia da Fixação Biológica do Nitrogênio (INCTFBN/Brazil).

\section{References}

Adesina MF, Lembke A, Costa R, Speksnijder A and Smalla K (2007) Screening of bacterial isolates from various European soils for in vitro antagonistic activity towards Rhizoctonia solani and Fusarium oxysporum: Site-dependent composition and diversity revealed. Soil Biol Biochem 39:2818-2828.

Adesemoye AO and Kloepper JW (2009) Plant-microbes interactions in enhanced fertilizer use efficiency. Appl Microbiol Biotechnol 85:1-12.

Ahmad F, Ahmad I and Khan MS (2006) Screening of free-living rhizospheric bacteria for their multiple plant growth promoting activities. Microbiol Res 163:173-181.

Ait Barka E, Nowak J and Clement C (2006) Enhancement of chilling resistance of inoculated grapevine plantlets with a plant growth promoting rhizobacterium, Burkholderia phytofirmans strain PsJN. Appl Environ Microbiol 72:7246-7252.

Altschul SF, Madden TL, Schaeffer AA, Zhang J, Zhang Z, Miller W and Lipman DJ (1997) Gapped BLAST and PSI-BLAST: a new generation of protein database search programs. Nucleic Acids Res 25:3389-3402.

Ambrosini A, Beneduzi A, Stefanski T, Pinheiro FG, Vargas LK and Passaglia LMP (2012) Screening of plant growth pro- moting rhizobacteria isolated from sunflower (Helianthus annuus L.). Plant Soil 356:245-264.

Antoun H and Prévost, D. (2006) Ecology of plant growth promoting rhizobacteria. In: Siddiqui, ZA (ed), PGPR: Biocontrol and Biofertilization. Springer, Dordrecht, The Netherlands, pp.1-38.

Araujo WL, Maccheroni Jr W, Aguilar-Vildoso CI, Barroso PAV, Saridakis HO and Azevedo JL (2001) Variability and interactions between endophytic bacteria and fungi isolated from leaf tissues of citrus rootstocks. Can J Microbiol 47:229236.

Asis CA and Adachi K (2003) Isolation of endophytic diazotroph Pantoea agglomerans and nondiazotroph Enterobacter asburiaefrom sweet potato stem in Japan. Lett Appl Microbiol 38:19-23.

Belimov AA, Kojemiakov AP and Chuvarliyev CV (1995) Interaction between barley and mixed cultures of nitrogen fixing and phosphate-solubilizing bacteria. Plant Soil 173:29-37.

Beneduzi A, Peres D, Vargas LK, Bodanese-Zanettini MH, Passaglia LMP (2008) Evaluation of genetic diversity and plant growth promoting activities of nitrogen-fixing bacilli isolated from rice fields in South Brazil. Appl Soil Ecol 39:311-320.

Bernstein B, Zehr EI and Dean RA (1995) Characteristics of Colletotrichum from peach, apple, pecan and others hosts. Plant Dis 79:478-482.

Boddey RM (1987) Methods for quantification of nitrogen fixation associated with gramineae. Crit Rev Plant Sci 6:209266.

Bogo A, Casa RT, Rufato L and Gonçalves MJ (2012) The effect of hail protection nets on Glomerella leaf spot in 'royal Gala' apple. Crop Protection 31:40-44.

Borges LGA, Dalla Vechia V and Corção G (2003) Characterization and genetic diversity via REP-PCR of Escherichia coli isolates from polluted waters in southern Brazil. FEMS Microbiol Ecol 45:173-180.

Bosco M, Baruffa E and Picard C (2006) Organic breeding should select for plant genotypes able to efficiently exploit indigenous probiotic rhizobacteria. Proceeding of European Joint Organization Congress, Vienna, Austria, pp 376-377.

Brown S (2012) Apple: In: Badenes ML and Byrne DH (eds), Fruit Breeding, Handbook of Plant Breeding, Springer Science Business Media, Philadelphia, PA, 329-367.

Caballero-Mellado J, Onofre-Lemus J, Estrada-de los Santos P and Martínez-Aguilar L (2007) The tomato rhizosphere, an environment rich in nitrogen-fixing Burkholderia species with capabilities of interest for agriculture and bioremediation. Appl Environ Microbiol 73:5308-5319.

Campbell CL and Madden LV (1990) Introduction to Plant Disease Epidemiology, Wiley \& Sons, New York, NY, 532 pp.

Chun J, Lee JH, Jung Y, Kim M, Kim S, Kim BK and Lim YW (2007) EzTaxon: a web-based tool for the identification of prokaryotes based on 16S ribosomal RNA gene sequences. Int J Syst Evol Microbiol 57:2259-2261.

Ciccillo F, Fiore A, Bevivino A, Dalmastri C, Tabacchioni S and Chiarini L (2002) Effect of two different application methods of Burkholderia ambifaria MCI 7 on plant growth and rhizospheric bacteria diversity. Environ Microbiol 4:238245.

Cole CV, Elliott ET, Hunt HW and Coleman DC (1978) Trophic interactions in soils as they affect energy and nutrient dy- 
namics. V. Phosphorus transformations. Micr Ecol 4:381387.

Conrath U, Pieterse CMJ and Mauch-Mani B (2002) Priming in plant-pathogen interactions. Trend Plant Sci 7:210-216.

Dimkpa CO, Merten D, Svatos A, Büchel G and Kothe E (2009) Metal-induced oxidative stress impacting plant growth in contaminated soil is alleviated by microbial siderophores. Soil Biol Biochem 41:154-162.

Döbereiner J (1988) Isolation and identification of root associated diazotrophs. Plant Soil 110, 207-212.

Engelhard, M., Hurek, T., Reinhold-Hurek, B. 2000. Preferential occurrence of diazotrophic endophytes, Azoarcus spp., in wild rice species and land races of Oryza sativa in comparison with modern races. Environ Microbiol 2:131-141.

Farina R, Beneduzi A, Ambrosini A, Campos SB, Lisboa BB, Wendisch V, Vargas LK and Passaglia LMP (2012) Diversity of plant growth-promoting rhizobacteria communities associated with the stages of canola growth. Appl Soil Ecol 55:44-52.

Felske A, Rheims H, Wokerink A, Stackebrandt E, Akkermans DL (1997) Ribosome analysis reveals prominent activity of an uncultured member of the class Actinobacteria in grasslands soils. Microbiology 143:2983-2989.

Fiddaman PJ and Rossal S (1993) The production of antifungal volatiles by Bacillus subtilis. J Appl Bact 74:119-126.

Freitas JR, Banerjee MR and Germida JJ (1997) Phosphate-solubilizing rhizobacteria enhance the growth and yield but not phosphorus uptake of canola (Brassica napus L.). Biol Fertil Soils 24:358-364.

Glick BR (2005) Modulation of plant ethylene levels by the bacterial enzyme ACC deaminase. FEMS Microbiol Lett 251:1-7.

Gyaneshwar P, James EK, Mathan N, Reddy PM, ReinholdHurek B and Ladha JK (2001) Endophytic colonization of rice by a diazotrophic strain of Serratia marcescens. J Bacteriol 183:2634-2645.

González E, Sutton TB and Correll JC (2006) Clarification of the etiology of Glomerella leaf spot and bitter rot of apple caused by Colletotrichum spp. based on morphology and genetic, molecular, and pathogenicity tests. Phytopathology 96:982-992.

Gozzo F (2003) Systemic acquired resistance in crop protection: from nature to chemical approach. J Agric Food Chem 51:4487-4503.

Hall TA (1999) BioEdit: a user-friendly biological sequence alignment editor and analysis program for Windows 95/98/NT. Nucleic Acids Symp Ser 41:95-98.

Hammer O, Harper DAT and Ryan PD (2001) PAST: paleontological statistics software package for education and data analysis version 2.09. Palaeontol Electro 4:9.

Hinton DM and Bacon CW (1995) Enterobacter cloacaeis an endophytic symbiont of corn. Mycopath 129:117-125.

Iniguez AL, Dong Y, Carter HD, Ahmer BMM, Stone JM and Triplett EW (2005) Regulation of enteric endophytic bacterial colonization by plant defenses. Mol Plant-Microbe Interact 18:169-178.

Karakurt H and Aslantas R (2010) Effects of some plant growth promoting rhizobacteria (PGPR) strains on plant growth and leaf nutrient content of apple. J Fruit Ornam Plant Res 18:101-110.

Kaschuk G, Hungria M, Andrade DS and Campo RJ (2006) Genetic diversity of rhizobia associated with common bean
(Phaseolus vulgaris L.) grown under no-tillage and conventional systems in Southern Brazil. Appl Soil Ecol 32:210220.

Kowata LS, Strapasson M, Challiol MA and May-De Mio LL (2010) Glomerella leaf spot in apple: validation of proposed diagrammatic scale and efficiency of fungicides. Ciênc Rural 40:1502-1508.

Kuklinsky-Sobral J, Araujo WL, Mendes R, Geraldi IO, Pizzirani-Kleiner AA and Azevedo JL (2004) Isolation and characterization of soybean-associated bacteria and their potential for plant growth promotion. Environ Microbiol 6:12441251.

Kürkcüoglu S, Degenhardt J, Lensing J, Al-Masri AN and Gau AE (2007) Identification of differentially expressed genes in Malus domestica after application of the non-pathogenic bacterium Pseudomonas fluorescens Bk3 to the phyllosphere. J Exp Bot 58:733-741.

Laheurte F and Berthelin J (1988) Effect of a phosphatesolubilizing bacteria on maize growth and root exudation over four levels of labile phosphorus. Plant Soil 105:11-17.

McInroy JA and Kloepper JW (1995) Survey of indigenous bacterial endophytes from cotton and sweet corn. Plant Soil 173:337-342.

Picardi C, Frascaroli E and Bosco M (2005) Recent knowledge on the ecology of plant-growth-promoting rhizobacteria helps to develop new concepts for organic plant breeding. Belicka I (ed), Proc Int Sem Environ Friendly Food Prod System: Requirement for Plant Breeding and Seed Production, State Stende Plant Breeding Station, Talsi, Latvia, pp. 39-42.

Pieterse CMJ, Van Wees SCM, Hoffland E, Van Pelt JA and Van Loon LC (1996) Systemic resistance in Arabidopsis induced by biocontrol bacteria is independent of salicylic acid accumulation and pathogenesis-related gene expression. Plant Cell 8:1225-1237.

Pieterse CMJ, Van Wees SCM, Van Pelt JA, Knoester M, Laan R, Gerrits H, Weisbeek PJ and Van Loon LC (1998) A novel signaling pathway controlling induced systemic resistance in Arabidopsis. Plant Cell 10:1571-80.

Pieterse CMJ, Ton J and Van Loon LC (2001) Cross-talk between plant defense signaling pathways: boost or burden? AgBiotechNet 3:1-8.

Ramamoorthy V, Viswanathan R, Raguchander T, Prakasam V and Samiyappan R (2001) Induction of systemic resistance by plant growth promoting rhizobacteria in crop plants against pests and diseases. Crop Protect 20:1-11.

Reiter B, Bürgmann H, Burg K and Sessitsch A (2003) Endophytic nifH gene diversity in African sweet potato. Can J Microbiol 49:549-555.

Rico A, Ortiz-Barredo A, Ritter E and Murillo J (2004) Genetic characterization of Erwinia amylovora strains by amplified fragment length polymorphism. J Appl Microbiol 96:302310 .

Rodrígues H and Fraga R (1999) Phosphate solubilizing bacteria and their role in plant growth promotion. Biotech Adv 17:319-339.

Rosenblueth M, Martinez L, Silva J and Martinez-Romero E (2004) Klebsiella variicola, a novel species with clinical and plant-associated isolates. Syst Appl Microbiol 27:27-35.

Sambrook J and Russel DW (2001) Molecular Cloning: A Laboratory Manual. Cold Spring Harbor Laboratory Press, New York, NY. 
Sessitsch A, Coenye T, Sturz AV, Vandamme P, Ait Barka E, Salles JF, Van Elsas JD, Faure D, Reiter B, Glick BR, et al. (2005) Burkholderia phytofirmans sp. nov., a novel plant-associated bacterium with plant-beneficial properties. Int J Syst Evol Microb 55:1187-1192.

Shannon CE and Weaver W (1949) The mathematical theory of communication. University of Illinois Press, Urbana, $132 \mathrm{pp}$.

Siddiqui ZA (2006) PGPR: Biocontrol and Biofertilization. Springer, Dordrecht, The Netherlands, $318 \mathrm{pp}$.

Souza R, Beneduzi A, Ambrosini A, Costa PB, Meyer J, Vargas LK, Schoenfeld R and Passaglia LMP (2013) The effect of plant growth-promoting rhizobacteria on the growth of rice (Oryza sativa L.) cropped in southern Brazilian fields. Plant Soil 366:585-603.

Sparks DL, Page AL, Helmke PA, Loeppert RH, Soltanpour PN, Tabatabai MA, Johnston CT and Sumner ME (1996) Methods of soil analysis. Part 3 - Chemical Methods. American Society of Agronomy-Soil Science Society of America, Madison, WI, 1390 pp.

St. Laurent A, Merwin IA and Thies JE (2008) Long-term orchard groundcover management systems affect soil microbial communities and apple replant disease severity. Plant Soil 304:209-225.

Sundara B, Natarajan V, Hari K (2002) Influence of phosphorus solubilizing bacteria on the changes in soil available phosphorus and sugarcane and sugar yields. Field Crops Res 77:43-49.

Tian F, Ding Y, Zhu H, Yao L and Du B (2009) Genetic diversity of siderophore-producing bacteria of tobacco rhizosphere. Braz J Microb 40:276-284.

Van Loon LC (1997) Induced Resistance in plants and the role of pathogenesis-related proteins. Eur J Plant Pathol 103:753765 .
Van Loon LC, Bakker PAHM and Pieterse CMJ (1998) Systemic resistance induced by rhizosphere bacteria. Annu Rev Phytopathol 36:453-83.

Verma SC, Singh A, Chowdhury SP and Tripathi AK (2004) Endophytic colonization ability of two deep-water rice endophytes, Pantoea sp. and Ochrobactrum sp. using green fluorescent protein reporter. Biotechnol Lett 26:425-429.

Vessey JK (2003) Plant growth promoting rhizobacteria as biofertilizers. Plant Soil 255:571-586.

Vial L, Groleau MC, Dekimpe V and Déziel E (2007) Burkholderia diversity and versatility: an inventory of the extracellular products. J Microbiol Biotechnol 17:14071429.

\section{Internet Resources}

PAST software, http://folk.uio.no/ohammer/past/ (accessed in August, 10, 2013).

EzTaxon Server version 2.1, http://www.eztaxon.org/ (accessed in June, 15, 2013).

\section{Supplementary Material}

The following online material is available for this article:

Table S1 - Effect of inoculation of various isolates.

Figure S1 - Dendrograms based on UPGMA cluster analysis.

Figure S2 - Differences of PGP traits between root and rhizospheric soil isolates.

Figure S3 - Phosphate solubilization halo size comparisons.

This material is available as part of the online article from http://www.scielo.br/gmb.

Associate Editor: Célia Maria de Almeida Soares

License information: This is an open-access article distributed under the terms of the Creative Commons Attribution License, which permits unrestricted use, distribution, and reproduction in any medium, provided the original work is properly cited. 